\title{
Purification and properties of a phytase from Candida melibiosica 2491
}

\author{
Danail Georgiev' ${ }^{1}$, Georgi Dobrev²,Stefan Shilev ${ }^{3 *}$ \\ ${ }^{1}$ University of Plovdiv, Faculty of Biology, Department of Microbiology, 24 Tsar Ivan Asen Str., Plovdiv 4000, Bulgaria, ${ }^{2}$ University of Food \\ Technology, Department of Biochemistry and Molecular Biology, 26 Maritsa Blvd., Plovdiv 4000, Bulgaria, ${ }^{3}$ Agricultural University - Plovdiv, \\ Department of Microbiology and Environmental Biotechnologies, 12 Mendeleev Str., Plovdiv 4000, Bulgaria
}

\section{A B S T R A C T}

\begin{abstract}
Aim: To characterize the enzyme phytase produced by phytase-active Candida melibiosica 2491 for subsecuent use in feed industry. Methods: C. melibiosica 2491 had been selected among 118 strains as the most productive strain of phytase. In present study, the enzyme was first purified through electrophoresis grade in four steps: precipitation with organic solvent, ultrafiltration, gel chromatography and Denaturing gel electrophoresis (SDS-PAGE). Results: Higher levels of purification were obtained using ethanol. The gel chromatography showed an elution maximum at 11-12 fractions that characterize the corresponding one as high-molecular weight phytase. The purification level was found to be 19.5 folds with specific enzyme activity of $2.75 \mathrm{U} / \mathrm{mg}$ protein and yield $-19.64 \%$. Furthermore, the molecular weight of purified phytase was estimated to $35.9 \mathrm{kDa}$, with optimum of $\mathrm{pH}$ - at 4.5 and optimum of temperature at $55^{\circ} \mathrm{C}$. Maximum phytase activity in case of whole cells was found at $50^{\circ} \mathrm{C}$, which was less than using the purified enzyme. It was activated through $5 \mathrm{mM}$ of $\mathrm{Ba}^{2+}$, $10 \mathrm{mM}$ of $\mathrm{Mn}^{2+}$ and $\mathrm{K}^{+}$ions. Total inhibition effect was achieved from $\mathrm{Fe}^{3+}, \mathrm{Hg}^{2+}$ and $\mathrm{Zn}^{2+}$. Copper ions $\left(\mathrm{Cu}^{2+}\right)$ in concentrations at $5 \mathrm{mM}$ conducted to partial inhibition effect, but at $10 \mathrm{mM}$ the phytase activity was equal to zero. Low inhibition effect was determined in case of cobalt ions $\left(\mathrm{Co}^{2+}\right)$ at concentrations of $10 \mathrm{mM}$. The phytase displayed broad substrate specificity and the $\mathrm{K}_{\mathrm{m}}$ for phytate was estimated to be $0.21 \mathrm{mM}$ under the experimental conditions, while $\mathrm{V}_{\max }-19.9 \mu \mathrm{m} / \mathrm{ml}$. Conclusion: Although the phytase produced by $C$. melibiosica 2491 is a promising enzyme to be used successfully in feed production, more investigations are needed to ensure its advantages.
\end{abstract}

Keywords: Candida melibiosica; Microbial phytase; Phosphate; Phytate degradation

\section{INTRODUCTION}

The phytases (myo-inositol hexakisphosphate 3- and 6- phosphohydrolase; EC 3.1.3.8 and EC 3.1.3.26) belong to a class of enzyme called histidine acid phosphatases (HAPs), which hydrolyse phytic acid by removing phosphate acidic groups. In matured grains of monocotyledonous and dicotyledonous plants, the phytic acid is the main accumulation form of phosphorus, representing 60 to $90 \%$ of whole organic phosphorus. Because of the strong chelating capacity, it is considered as an antinutritive factor as forming insoluble complexes with important nutritional metallic ions like calcium, zinc, magnesium, iron, etc., decreasing their bioavailability and assimilation. The organic bound phosphorus in phytic acid is not metabolized in monogastric animals like pigs, ducks and fishes, as well as in humans, due to the lack of enzyme phytase. This conducts to phosphorus contamination in areas with intensive animal husbandry.
Therefore, the phytic acid reduction in grains food through their enzymatic hydrolisis will increase the bioavailability. The phytases are synthesize by bacteria of genus Aerobacter (Greiner et al., 1993), Bacillus (Hartree, 1972), Enterobacter (Vochra et al., 2011), Klebsiella (Segueilha et al., 1992), fungus of genus Aspergillus (Segueilha, 1993) and yeast of genus Arxula, Rhodotorula, Candida, Clavispora, Debaryomyces, Hanseniaspora, Kluyveromyces, Metchnikowia, Schwanniomyces, Pichia, Saccharomyces, Schwanniomyces and Torulaspora (Choi et al., 2001, In et al., 2009, Laemmli, 1970, Nayini et al., 1984, Quan, 2002). During the last years the interest to yeast phytase marks a great increment, verified through the increased amount of scientific papers.

Candida melibisioca 2491 is a yeast strain, which has been widely used as biocatalyst in yeast based biofuel cell, a technology prominent to bioremediation (Hubenova Y et al., 2014), biosynthesis (Hubenova, et al., 2017) and simultaneously electricity generation (Babanova et al., 2011).

\footnotetext{
${ }^{*}$ Corresponding author:

Stefan Shilev, Agricultural University - Plovdiv, Department of Microbiology and Environmental Biotechnologies, 12 Mendeleev Str., Plovdiv 4000, Bulgaria. E-mail: stefan.shilev@au-plovdiv.bg
}

Received: 08 March 2018; $\quad$ Accepted: 21 September 2018 
The exoelectrogenic properties of C. melibiosica are proved to occur by means of both mechanisms of extracellular electron transfer - direct and by synthesis of endogenous mediator (Hubenova \& Mitov, 2015a, Hubenova \& Mitov, 2015b).

The aim of present study was to characterize the enzyme phytase produced by Candida melibiosica 2491 with the purpose to be used in feed industry.

\section{MATERIALS AND METHODS}

\section{Microorganism and culture conditions}

C. melibiosica 2491 had been selected among 118 strains as the most productive strain. It was cultivated in Georgiev medium according the conditions described by Stanchev et al., 2010.

\section{Measurement of enzymatic activity}

Phytase activity was determined by measuring the amount of liberated inorganic phosphate using the method of Engelen (Engelen., 1994). The optical density of solution was measured at $415 \mathrm{~nm}$. One unit phytase activity is equivalent to the production of $1 \mu \mathrm{mol}$ inorganic orthophosphate and is denoted as $\mathrm{U} / \mathrm{g}$ dry biomass (Segueilha et al., 1992, Lambrechts et al., 1992).

\section{Preparation of cell-free extract}

The yeast cells were disrupted by vortex applying the method described by Georgiev et al., 2009.

\section{Protein determination}

The total protein content was determined using the Hartree method (1972).

\section{Phytase purification}

The cell-free extract was centrifuged at $10000 \mathrm{rpm}$ for $10 \mathrm{~min}$ and the supernatant was used for purification of the enzyme on classic biochemical method.

\section{Precipitation with organic solvent}

The precipitation of supernatant was done with three kinds of organic solvents - ethanol, isopropanol and acetone in different proportions (precipitator: supernatant) - 0.5:1.0, 1.0:1.0, 1.5:1.0, 2.0:1.0 and 2.5:1.0. Small portions of preliminary cooled at $-15^{\circ} \mathrm{C}$ organic solvent, were added agitating vigorously in ice/water bath. After the solvent addition, the sample was homogenized for $5 \mathrm{~min}$ and placed in frige at $-4^{\circ} \mathrm{C}$ for $30 \mathrm{~min}$ to improve the precipitate formation. Following, the sample was centrifuged at $3500 \mathrm{rpm}$ for $10 \mathrm{~min}$, the solvent was removed, while the precipitated enzyme was dissolved very carefufly in sodium acetate buffer.

\section{Ultrafiltration}

Consecutively, the obtained enzyme solution was subjected to additional purification and concentration by ultrafiltration with cell Amicon 52 (vol. $50 \mathrm{ml}$ ). For that purpose, polysulfone membranes with different pore diameter $(25$ and $50 \mathrm{kDa}$ ) were applied. The process was carried out at room temperature.

\section{Gel chromatography by Sephadex G-75}

The gel chromatography was conducted on FPLC, Pharmacia Biotech. and Pharmacia K26/700 column with diameter $26 \mathrm{~mm}$ and length $700 \mathrm{~mm}$. The column was filled with Sephadex G-75. Before loading the samle in the column, the ultraconcentrate was subjected to centrifugation at $9000 \mathrm{rpm}$ for $10 \mathrm{~min}$. The sample was loaded with $26.6 \mathrm{mg}$ of protein. The empty volume was determined with $0.1 \%$ dextran blue solution. The elution was done with $0.05 \mathrm{M} \mathrm{NaCl}$ solution and velocity of flow of $19.8 \mathrm{ml} / \mathrm{h}$. Fractions of $10.0 \mathrm{ml}$ were collected and analysed for protein content and phytase activity.

\section{SDS-PAGE electrophoresis}

SDS-PAGE was performed using the method of Laemmli (1970). We used a separating gel with $15 \%$ acrilamide and concentrating gel with $6 \%$ acrilamide. The standards were introduced in the wells at concentration of $40 \mu \mathrm{g}$, while the samples were used in concentration of till $100 \mu \mathrm{g}$ of protein per well. The electrophoretic separation was performed at field strength of $20 \mathrm{~mA}$.

The electropherograms were stained for $20 \mathrm{~min}$ with continuous shaking of solution with the next content: $40 \%$ ethanol, $7 \%$ acetic acid and $0.2 \%$ Coomassie brilliant blue $\mathrm{R}-250$. The decolorization was carried out with a solution of $10 \%$ ethanol and $7 \%$ of acetic acid shaking continuosly.

\section{Molecular weight estimation}

The molecular weight of the purified phytase was estimated through gel filtration on a HiPrep ${ }^{\circledR}$ 16/60 Sephacryl S-300 HR column and by SDS-PAGE of phytase from Candida melibiosica 2491. Marquers used: Soyabean trypsin inhibitor (20.000), Bovine pancreatic trypsine (24.000), Bovine erythrocyte carbonic anhydrase (29.000), Glyceraldehyde 3-phosphate from rabbit muscle (36.000), Ovalbumin from chicken eggs (45.000), Glutamate dehydrogenase from bovine liver (55.000), Bovine serum albumin (66.000), Phosphorylase B from rabbit muscle (97.000), $\beta$-galactosidase from E. coli (116.000), Myosin porcine heart (200.000). The SDS-PAGE was performed according to the method of Laemmli with a $10 \%$ gel concentration. Native-PAGE was performed using an 8 $\%$ gel concentration. They were stained with $0.5 \%(\mathrm{w} / \mathrm{v})$ Coomassie Brilliant Blue R-250. 


\section{RESULTS}

\section{Phytase purification}

\section{Precipitation with organic solvent}

A precipitation of the supernatant obtained after cell disintegration and centrifugation was done. Three kinds of solvents were used for the precipitation: ethanol, isopropanol and acetone, in different ratio (precipitator: supernatant) - 0.5:1.0, 1.0:1.0, 1.5:1.0, 2.0:1.0 and 2.5:1.0 (Table.1). The use of ratio-1.0:1.0 of ethanol: homogenate conducted to higher yield of the enzyme of $48.2 \%$, higher specific enzyme activity, $1.195 \mathrm{U} / \mathrm{mg}$ of protein and higher level of purification -8.5 folds. When acetone was used as organic precipitator, high levels of purification are obtained from 7.67 for ratio 1:1 and 7.22 for ratio 1.5:1.0, while the specific enzyme activity was also with high values, 1.081 $\mathrm{U} / \mathrm{mg}$ and $1.018 \mathrm{U} / \mathrm{mg}$ of protein, respectively. On the other hand, the yields were found to be quite low, $19.3 \%$ and $20.0 \%$. In case of using isopropanol, the results were too low and that is why it is not suitable for precipitation of phytase from Candida melibiosica 2491.

The enzyme obtained after ethanol precipitation (1:1 ratio) was subjected to ultrafiltration with purpose to additional purification and concentration.

\section{Selection of proper membrane for ultrafiltration of the isolate Candida melibiosica 2491.}

The ultrafiltration is a common tool in enzyme application because: the enzymes are not subjected to termic treatments o chemical influences; the method is easy for realization and low cost. This process ensures the simultaneous concentration and purification of the enzymes from the accompanying compounds. The enzyme solution is in contact with a semipermeable membrane.

In present study, we used three kinds of polysulfone membranes with different pore diameters $-25 \mathrm{kDa}$ and $50 \mathrm{kDa}$ with purpose to select the most proper ultrafiltration. The results are presented in Table. 2.

\section{Gel filtration of Sephadex G-75}

The enzyme obtained after ultrafiltration through membrane PS 50 was subjected to fractionation using gel-filtration with Sephadex G-75 (recommended weight of the molecules are 3-70 kDa). The protein separation according this method is based on the difference in the molecular weights. Gel-filtration was carried out without chemical or thermic influence on the molecules. That is why this method is very suitable for enzymes.

The elution profile of the enzyme is presented in Fig. 1. The enzyme protein runs out in the first elution fractions (from 8 to 13) with a maximum in fraction 11-12. This shows that the phytase of C. melibiosica 2491 belongs to the high-molecular weight proteins compared to the other ones produced by the isolate. The most of low-molecular weight proteins are eluted in 26-41 fractions.

\section{$S D S-P A G E$}

The putrity of enzyme was determined throught gel electrophoresis with denaturing conditions. The maximum active protein fraction after gel filtration of Sephadex G-75 appeared in a single gel band. This means that a homogenous fraction was obtained (Fig. 2).

It is known that to prove the homogeneity of an enzyme protein, other methods based on different principles should be also applied. During this procedure, proteins with similar molecular weight will give one peak and remain unseparated.

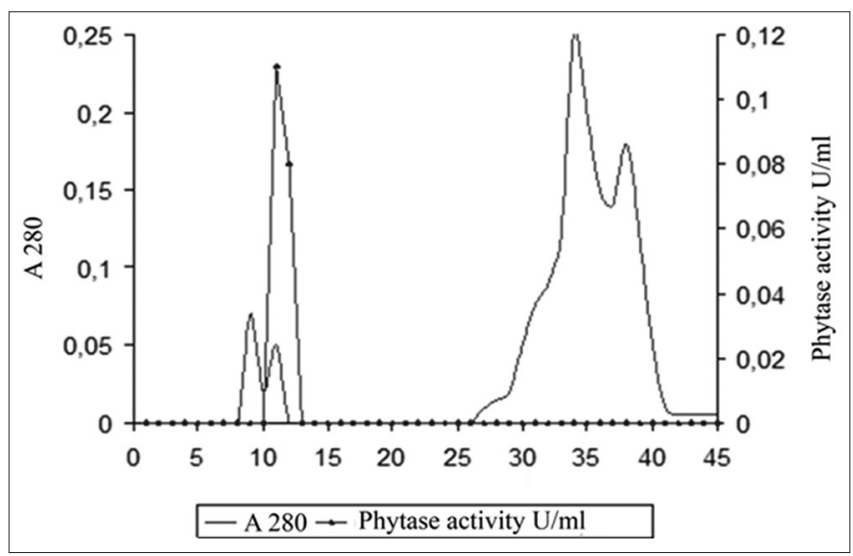

Fig. 1: Elution profile of phytase from Candida melibiosica 2491 during gel-filtration with Sephadex G-75.

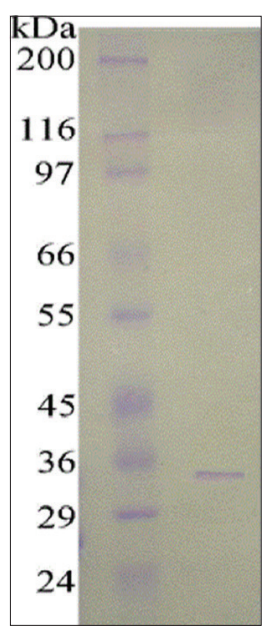

Fig. 2: SDS-PAGE of phytase of Candida melibiosica 2491. Markers of band A: Soyabean trypsin inhibitor (20.000), Bovine pancreatic trypsine (24.000), Bovine erythrocyte carbonic anhydrase (29.000), Glyceraldehyde 3-phosphate from rabbit muscle (36.000), Ovalbumin from chicken eggs (45.000), Glutamate dehydrogenase from bovine liver (55.000), Bovine serum albumin (66.000), Phosphorylase B from rabbit muscle (97.000), $\beta$-galactosidase from E. coli (116.000), Myosin porcine heart (200.000). 
In order to obtain a phytase with high purity is necessary to apply scheme that includes precipitation with organic solvent, ultraconcentration and column chromatography of Sephadex G-75. Based on the results shown on Figure 2, is possible to assume with high probability that the obtained enzyme is homogeneous. The purification level was found to be 19.5 folds (Table 3 ) with specific enzyme activity of $2.75 \mathrm{U} / \mathrm{mg}$ protein and the yield $-19.64 \%$.

\section{Effects of $\mathrm{pH}$ and temperature on enzymatic activity and stability}

The influence of $\mathrm{pH}$ of medium on enzyme activity was studied between pH 2.0 and pH 10.0 using step of 1.0 (Fig. 3).
The $\mathrm{pH}$ profile of activity of studied enzyme showed that the phytase of Candida melibiosica 2491 is active in acid range of $\mathrm{pH}$, i.e., this is an acid phytase. The enzyme showed around $60 \%$ of its activity in the range between $\mathrm{pH} 3.5$ and $\mathrm{pH}$ 5.0, while the maximum was found at $\mathrm{pH} 4.5$. The extreme acid and alkaline values conducted to a sudden fall, although without full loss of the activity.

\section{Influence of temperature of reactive medium on activity of the purified enzyme}

The influence of temperature on the hydrolysis of sodium phytate was studied at 30, 37, 45, 50, 55, 60, 65, 70, 75 and $80^{\circ} \mathrm{C}$ and optimal $\mathrm{pH}$ of 4.5 . Maximum activity was found

Table 1: Investigation of the influence of ratio between the type of organic solvent and enzyme homogenate on the purification level of phytase of Candida melibiosica 2491

\begin{tabular}{|c|c|c|c|c|c|c|c|}
\hline Ratio precipitator: enzyme & $\mathrm{V}, \mathrm{ml}$ & $\begin{array}{l}\mathrm{PhA} \text {, } \\
\mathrm{U} / \mathrm{ml}\end{array}$ & $\begin{array}{c}\text { Total } \\
\text { activity, } \mathrm{U}\end{array}$ & Yield, \% & $\begin{array}{l}\text { Protein, } \\
\mathrm{mg} / \mathrm{ml}\end{array}$ & $\begin{array}{c}\text { Spec. activity } \\
\text { U/mg }\end{array}$ & $\begin{array}{l}\text { Purification, } \\
\text { folds }\end{array}$ \\
\hline Homogenate & 5.00 & 0.56 & 2.8 & 100 & 3.966 & 0.141 & 1 \\
\hline \multicolumn{8}{|l|}{ Ethanol/supernatant } \\
\hline $0.5: 1.0$ & 5.00 & 0.1 & 0.5 & 17.9 & 0.138 & 0.725 & 5.14 \\
\hline $1.0: 1.0$ & 5.00 & 0.27 & 1.35 & 48.2 & 0.226 & 1.195 & 8.5 \\
\hline $1.5: 1.0$ & 5.00 & 0.21 & 1.05 & 37.5 & 0.306 & 0.686 & 4.87 \\
\hline 2.0:1.0 & 5.00 & 0.12 & 0.6 & 21.4 & 0.429 & 0.280 & 1.99 \\
\hline $2.5: 1.0$ & 5.00 & 0.11 & 0.55 & 19.6 & 0.362 & 0.304 & 2.16 \\
\hline \multicolumn{8}{|l|}{ Acetone/Supernatant } \\
\hline $0.5: 1.0$ & 5.00 & 0 & 0 & 0 & 0.085 & 0 & 0 \\
\hline 1.0:1.0 & 5.00 & 0.107 & 0.54 & 19.3 & 0.099 & 1.081 & 7.67 \\
\hline $1.5: 1.0$ & 5.00 & 0.111 & 0.56 & 20.0 & 0.109 & 1.018 & 7.22 \\
\hline 2.0:1.0 & 5.00 & 0.095 & 0.48 & 17.1 & 0.161 & 0.590 & 4.18 \\
\hline $2.5: 1.0$ & 5.00 & 0.076 & 0.38 & 13.6 & 0.204 & 0.373 & 2.65 \\
\hline \multicolumn{8}{|l|}{ Isopropanol/supernatant } \\
\hline $0.5: 1.0$ & 5.00 & 0.1 & 0.5 & 17.9 & 0.145 & 0.69 & 4.89 \\
\hline $1.0: 1.0$ & 5.00 & 0.24 & 1.2 & 42.9 & 0.292 & 0.82 & 5.82 \\
\hline $1.5: 1.0$ & 5.00 & 0.12 & 0.6 & 21.4 & 0.341 & 0.35 & 2.48 \\
\hline 2.0:1.0 & 5.00 & 0.04 & 0.2 & 7.1 & 0.235 & 0.17 & 1.21 \\
\hline $2.5: 1.0$ & 5.00 & 0 & 0 & 0 & 0.189 & 0 & 0 \\
\hline
\end{tabular}

Table 2: Ultrafiltration of homogenate of disintegrated cells of Candida melibiosica 2491 through membranes with different pore diameter

\begin{tabular}{|c|c|c|c|c|c|c|}
\hline \multirow[t]{2}{*}{ Membrane } & \multicolumn{3}{|c|}{ PS 25} & \multicolumn{3}{|c|}{ PS 50} \\
\hline & Isolate & UC & Permeate & Isolate & UC & Permeate \\
\hline Total volume, $\mathrm{ml}$ & 50 & 5 & 45 & 50 & 5 & 45 \\
\hline Protein, mg/ml & 0.226 & 1.63 & 0.06 & 0.226 & 1.82 & 0.04 \\
\hline Total protein, mg & 11.3 & 8.21 & 2.7 & 11.3 & 9.1 & 1.8 \\
\hline $\mathrm{PhA}, \mathrm{U} / \mathrm{ml}$ & 0.270 & 2.3 & 0 & 0.270 & 2.64 & 0 \\
\hline Total PhA, U & 13.5 & 11.5 & 0 & 13.5 & 13.2 & 0 \\
\hline Specific PhA, U/mg & 1.195 & 1.41 & 0 & 1.195 & 1.45 & 0 \\
\hline Yield, \% & 100 & 85.19 & 0 & 100 & 97.78 & 0 \\
\hline Purification, folds & 1 & 1.18 & 0 & 1 & 1.21 & 0 \\
\hline
\end{tabular}

Table 3: Phytase purification steps of Candida melibiosica 2491

\begin{tabular}{|c|c|c|c|c|c|}
\hline Steps & Total activity, U & Total protein, $\mathrm{mg}$ & Specific activity, U/mg & Level of purification, folds & Yield, \% \\
\hline Homogenate & 2.8 & 19.83 & 0.141 & 1 & 100 \\
\hline Isolate & 1.35 & 1.13 & 1.195 & 8.5 & 48.2 \\
\hline Ultraconcentrate & 1.32 & 0.91 & 1.45 & 10.28 & 47.14 \\
\hline Sephadex G-75 & 0.55 & 0.20 & 2.75 & 19.5 & 19.64 \\
\hline
\end{tabular}


at $55^{\circ} \mathrm{C}$, which is $5^{\circ} \mathrm{C}$ less than those measured in case of whole cells. This fact shows that the purification decrease the temperature stability of the enzyme. Temperatures higher than $60^{\circ} \mathrm{C}$ conducted to a sudden decrease of activity disappearing at $75^{\circ} \mathrm{C}$ (Fig. 4). This fact could be an obstacle for that phytase to be used as amendment of fodders subjected to pelleting at high temperatures.

\section{Effects of metal ions and chemical reagents}

The effect of metal ions on phytase activity was studied using sodium phytate as substrate (Table. 4). The phytase activity was completely inhibited by $\mathrm{Fe}^{3+}, \mathrm{Hg}^{2+}$ and $\mathrm{Zn}^{2+}$. Copper ions $\left(\mathrm{Cu}^{2+}\right)$ were found to suppress strongly the enzyme in concentration of $5 \mathrm{mM}$, while in concentration of $10 \mathrm{mM}$ the activity of the enzyme was zero. A low inhibiting effect was found in case of $\mathrm{Co}^{2+}$ in concentration of $10 \mathrm{mM} . \mathrm{Ba}^{2+}$ in concentration of $5 \mathrm{mM}$ and $\mathrm{Mn}^{2+}$ and $\mathrm{K}^{+}$ in concentration of $10 \mathrm{mM}$ activated the enzyme activity. Choi and collaborators (2001) found that $\mathrm{Ba}^{2+}$ increase the enzyme activity in Bacillus sp. KHU-10 with $46 \%$ when $1 \mathrm{mM}$ of $\mathrm{CaCl}_{2}$ was added in reaction medium.

\section{Substrate specificity and enzyme kinetics}

The substrate specificity of phytase was studied when the concentration of salts in medium was $0.5 \mathrm{mM}$. The hydrolysis was done at $55^{\circ} \mathrm{C}$ and $\mathrm{pH} 4.5$. We accepted

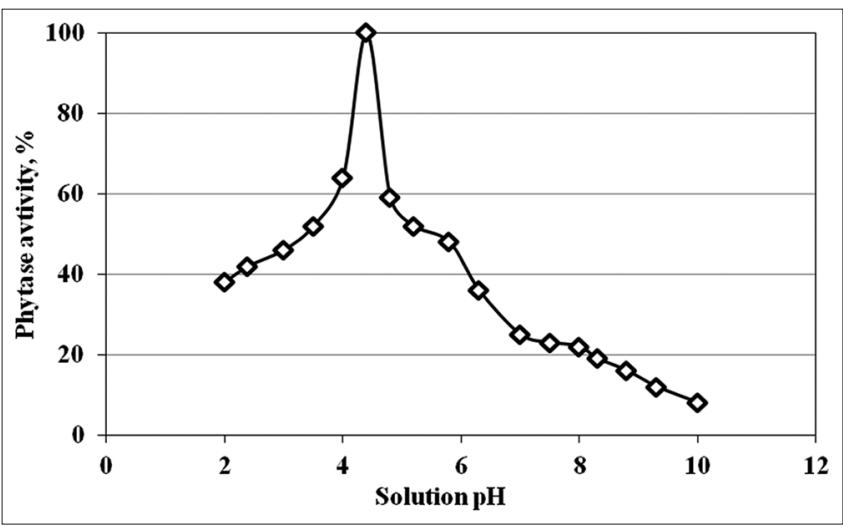

Fig. 3: Effects of medium $\mathrm{pH}$ on purified phytase activity.

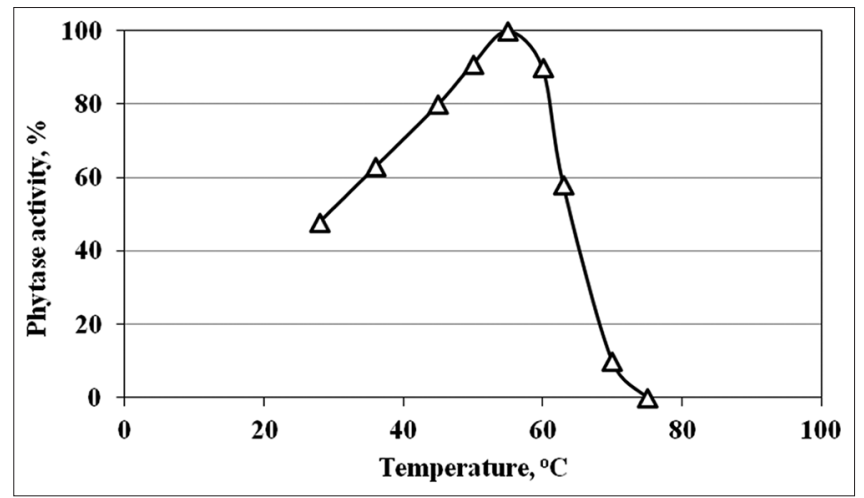

Fig. 4: Temperature profile of activity of purified phytase of Candida melibiosica 2491.

Emir. J. Food Agric • Vol $30 \bullet$ Issue $11 \bullet 2018$ than enzyme activity in case of sodium phytate is $100 \%$. The results presented in Table 5 showed that the enzyme possess relatively wide substrate specificity. The activity was $65 \%$ higher in case of potassium phytate that make this phytase suitable for supplementing in fooders with high content of phytates. The supplementation of phytase of Candida melibiosica 2491 could increment significantly the nutrient value of fodders because of increased activity towards potassium phytate, while the addition of whole cells would increase and protein content.

Determination of kinetic parameters $\mathrm{K}_{\mathrm{m}}$ and $\mathrm{V}_{\max }$ of hydrolysis of sodium phytate was done at $55^{\circ} \mathrm{C}$ and $\mathrm{pH} 4.5$. These conditions have been described as optimal for the enzyme activity. For the purpose of the experiment, we used the graphic method of Lineweaver-Burke. During the hydrolysis of sodium phytate $\mathrm{K}_{\mathrm{m}}$ was $0.21 \mathrm{mM}$, while $\mathrm{V}_{\text {max }}-19.9 \mu \mathrm{M} / \mathrm{ml}$ (Fig. 5).

\section{Determination of molecular weight of the partially purified enzyme}

Molecular weight of the phytase of Candida melibiosica 2491 determined through SDS-PAGE was 35,9 $\mathrm{kDa}$ with mobility of $76.05 \mathrm{~mm}$ (Fig. 6).

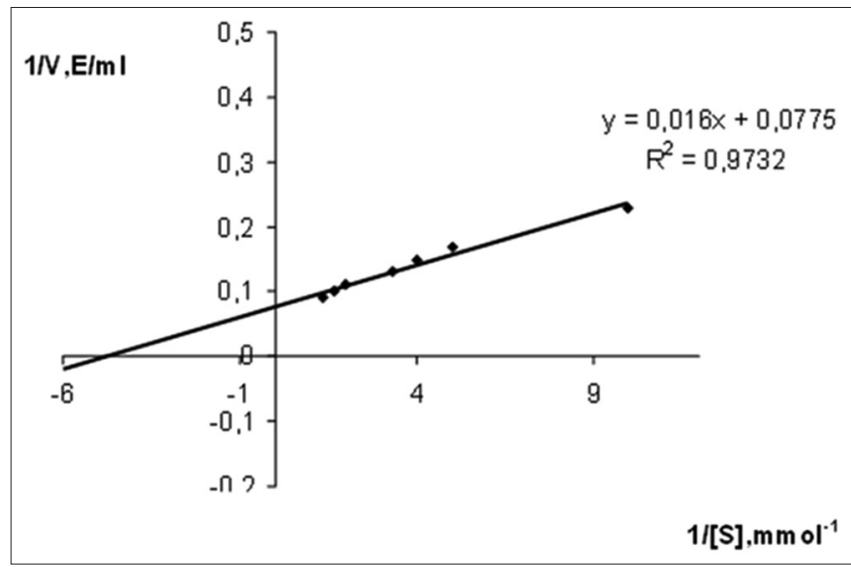

Fig. 5: Kinetic characteristics of the purified phytase of Candida melibiosica 2491.

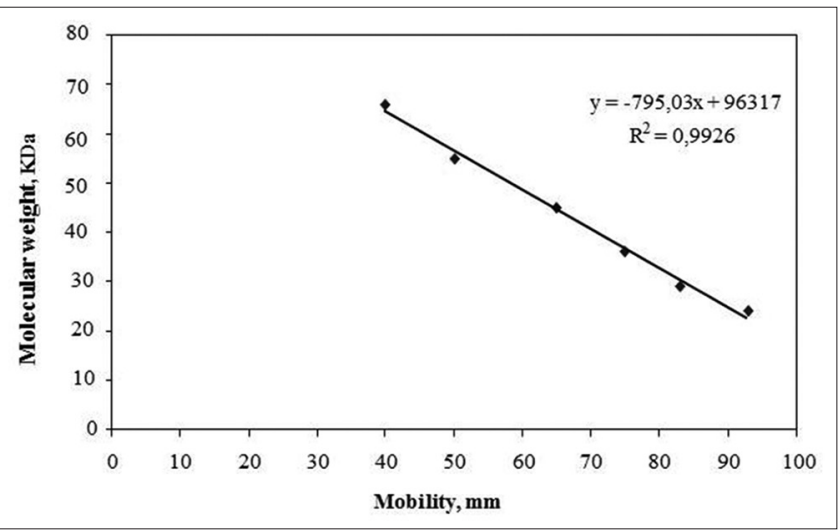

Fig. 6: Dependence of the mobility from the molecular weight of phytase of Candida melibiosica 2491. 


\section{DISCUSSION}

According to Spier et al. (2011), phytate-degrading enzymes described so far, belongs to the acidic type, with optimal $\mathrm{pH}$ ranges from 4.5 to 6.0. Besides, the lower $\mathrm{pH}$ optimum of 3.5 in the investigation of Qvirist et al. (2017) corresponded to the reported $\mathrm{pH}$ of the pig stomach, meaning that the phytase is highly suitable for use in feed production. Those purified phytase of P. kudriavzevii (TY1322) showed two $\mathrm{pH}$ optima, at pH 3.5 and 5.5, and one temperature optimum at $55^{\circ} \mathrm{C}$, that correspond with our findings.

The comparison of optimal $\mathrm{pH}$ value of phytase activity of Candida melibiosica 2491 that was 4.5, with other phytases, shows similarity with most of the literature sources. Intracellular phytase of baker's yeasts was with $\mathrm{pH}$ optimum at 4.6 (Nayini and Markakis, 1984), phytase of E. coli - at pH 4.5 (Greiner et al., 1993), S. castelli phytase - at $\mathrm{pH}$ 4.4 (Segueilha et al., 1993) and Penicillium simplicissimum phytase - at pH 4.0 (Tseng et al., 2000). In a comparison study between Aspergillus and bacterial phytases, Elhadi and collaborators (2011) reported about displayed optimal activity of Aspergillus, E. coli and Klebsiella phytases in acidic $\mathrm{pH}$ range, while Bacillus phytase was found in the neutral $\mathrm{pH}$.

\begin{tabular}{|c|c|c|}
\hline Reagents & $5 \mathrm{mM}$ & $10 \mathrm{mM}$ \\
\hline Control & 100 & 100 \\
\hline $\mathrm{BaCl}_{2}$ & 133 & 100 \\
\hline $\mathrm{CaCl}_{2}$ & 100 & 100 \\
\hline $\mathrm{CoCl}_{2}$ & 100 & 89 \\
\hline $\mathrm{Mg} \mathrm{Cl}_{2}$ & 100 & 100 \\
\hline $\mathrm{Mn} \mathrm{Cl}_{2}$ & 100 & 111 \\
\hline $\mathrm{KCl}$ & 100 & 120 \\
\hline $\mathrm{CuCl}_{2}$ & 22 & 0 \\
\hline $\mathrm{FeCl}_{3}$ & 0 & 0 \\
\hline $\mathrm{Hg}_{2} \mathrm{Cl}_{2}$ & 0 & 0 \\
\hline $\mathrm{ZnSO}_{4}$ & 0 & 0 \\
\hline
\end{tabular}

Table 5: Substrate specificity of purified phytase of Candida melibiosica 2491

\begin{tabular}{lc}
\hline Substrate & $\begin{array}{c}\text { Activity, \% of } \\
\text { maximum }\end{array}$ \\
\hline Sodium phytate (Control) & 100 \\
Potassium phytate & 165 \\
Adenosine 5 - triphosphate & 60 \\
Sodium -1 - naphtyle phosphate & 55 \\
monohydrate & \\
Adenosine 5 - diphosphate & 20 \\
Disodium 1 - naphtyl phosphate & 20 \\
Disodium phenyl phosphate & 10 \\
Sodium - $\beta$ - glycerophosphate. $5 \mathrm{H}_{2} \mathrm{O}$ & 5 \\
Disodium - $\beta$ - glycerophosphate & 0 \\
O - ( - 4 - nitrilophenyl - phosphoric) & 0 \\
choline & \\
L- $\boldsymbol{\alpha}-$ phosphatidylcholine & 0 \\
\hline
\end{tabular}

In previous study, a C. melibiosica 2491 was described as a promising strain (Georgiev et al., 2013). In present one, when cells of C. melibiosica 2491 were used, the phytase is active in a wider range of $\mathrm{pH}$ from 4.0 to 8.5 with optimum again at 4.5 . The activity at $\mathrm{pH} 4.0$ is $88 \%$, while at $\mathrm{pH}$ 8.5 is $80 \%$ of the maximum activity. In case of purified phytase at $\mathrm{pH} 8.5$ the activity is only $18.9 \%$. It seems that the presence of concomitant compounds in the cells plays a role of enzyme protectors, which explain the wider $\mathrm{pH}$ range of activity of intracellular enzyme.

We found the maximum activity of phytase of C. melibiosica 2491 at $55^{\circ} \mathrm{C}$, that was $5^{\circ} \mathrm{C}$ lower compared with the activity of whole cells. According to the survey done by Yao and collaborators (2012), the phytase produced from yeasts present a temperature optimum from 40 to $70^{\circ} \mathrm{C}$ in Candida krusei and Schwanniomyces occidentalis, respectively. In the same time, the enzyme is active at $\mathrm{pH}$ range between 4.0 and 5.0. Although in the same review the temperature optimum for bacterial phytase is similar, the optimal $\mathrm{pH}$ range is quite wide -4.0 to 8.5. Bacillus phytase was found to be more resistant to heat treatment comparing to other bacterial and Aspergillus phytases (Elhadi et al., 2011). In case of phytase from fungi, the optimal $\mathrm{pH}$ range is expectedly much lower, from 1.3 to 6.0 , taking into account that the fungi's cell optimum is also there. In the same time the temperature optimum is 40 and $70^{\circ} \mathrm{C}$.

According literature data, $\mathrm{Mg}^{2+}$ possess strong inhibition effect on the phytase activity of C. krusei WZ-001 (Quan et al., 2001), but $\mathrm{Mg}^{2+}$ showed medium retarding effect in case of phytase of Cladosporium sp. FP-1 (Quan, 2002). Greiner et al. discussed that the decreasing of phytase activity, when iron and copper ions were present in medium, is due to lower substrate concentration because of low solubility of complex metal ion-phytate. Other authors informed that the phytase activity of $S$. cerevisiae was completely inhibited by $\mathrm{Ba}^{2+}, \mathrm{Ca}^{2+}, \mathrm{Co}^{2+}, \mathrm{Cu}^{2+}, \mathrm{Fe}^{2+}$, $\mathrm{Fe}^{3+}$ and $\mathrm{Hg}^{2+}$ (In et al., 2009). Qvirist and coworkers (2017) reported that no influence from $\mathrm{Ca}^{2+}$ and $\mathrm{Mg}^{2+}$ at any of the tested concentrations, an almost linearly increased inhibition from $\mathrm{Cu}^{2+}$ with increasing ion concentration and a complete inhibition from $\mathrm{Fe}^{2+}$ already at $1 \mathrm{mM}$ concentration in case of both TY13wt and TY1322 phytases from P. kudriavzevii.

The $\mathrm{K}_{\mathrm{m}}$ parameters of other yeast phytases studied in the scientific literature were determined between 38 and 250 mM (Quan et al., 2001; Guo et al., 2007; Nayimi and Markakis, 1984; Segueilha et al., 1992; Sano et al., 1999). In case of Pichia anomala the cell-bound phytase possessed $\mathrm{K}_{\mathrm{m}}$ of $0.20 \mathrm{mM}$ and $\mathrm{V}_{\text {max }}$ of $6.34 \mu \mathrm{mol} / \mathrm{ml}$ (Vohra et al., 2011). These data shown that the phytase of Candida melibiosica 2491 has similar parameters compared with the cell-bound enzyme of $P$. anomala.

Emir. J. Food Agric • Vol $30 \bullet$ Issue 11 
A new type of phytase was isolated from Aspergillus ficuum NTG-23. The enzyme possesses a molecular weight of $65.5 \mathrm{kD}$ a that was determined using a SDS-PAGE. It has a oprimal $\mathrm{pH}$ of 1.3 , optimal temperature of $67^{\circ} \mathrm{C}$ and $\mathrm{K}_{\mathrm{m}}$ and $\mathrm{V}_{\text {max }} 0.295 \mathrm{mM}$ and $55.9 \mathrm{nmol} / \mathrm{min}$, respectivelly (Zhang et al., 2010). Comparing to other Aspergillus phytase, those purified by Aspergillus niger FS3 displayed high affinity for phytate, and the $\mathrm{Km}$ was determined at $0.52 \mathrm{mM}$ (Spier et al., 2011). Vohra and co-authors (2011) informed that the enzyme of Pichia anomala is homohexamer possessing molecular weight of $64 \mathrm{kDa}$, proved by native PAGE. On the other hand, Quan \& collaborators (2002) found that the enzyme in Candida crusei WZ-001 isolated from soil of chanise province Dailian is located in periplasm. It has molecular weight of $75 \mathrm{kDa}$ and is composed by two subunits. It seems that the similarity in some of the characteristics of both enzymes is due to their affiliation to the same genera.

Similar experiments were realized by other scientists with the purpose to select and characterize phytase producing yeast strains. In this sense, Qvirist et al., 2017 studied a strain of Pichia kudriavzevii (TY1322), with highly improved phytate-degrading capacity. The capacity of the strain was increased through UV mutation. The obtained mutant showed biomass-specific phytate degradation, which is about 8 times higher compared with the wild-type strain.

The extracellular specific phytase activities were significantly higher than the intracellular phytase-specific activities in a study of fourteen yeast strains conducted by Nuobariene and collaborators in 2011. On the other hand, Yao and colleagues (2012) found, that a limited number of phytases have been reported and studied, which could be useful for the nutritional and environmental requirements. Finally, we can suggest that Candida melibiosica 2491 seems to be a very promising candidate for application in feed industry.

\section{CONCLUSIONS}

The suplimentation of enzymes to the feed is an important tool to increase the quality of animal husbandry production. That is why precission and more research are needed in order to meet nutritional and ecological requirements of the sector, especially in case of Candida melibiosica 2491.

\section{Authors' contributions}

Study concepts and design: D.Georgiev, G.Dobrev; Material preparation: D.Georgiev; Literature research: D.Georgiev, S.Shilev; Date analysis/interpretation, Manuscript Preparation and definition of intellectual content: D.Georgiev, S.Shilev; Manuscript English language translation and editing S.Shilev.; Manuscript revision/ review S.Shilev., D.Georgiev; Manuscript final version approval: All authors read and approved the manuscript.

\section{REFERENCES}

Babanova, S., Y. Hubenova, M. Mitov and P. Mandjukov. 2011. Uncertainties of yeast-based biofuel cell operational characteristics. Fuel Cells. 11: 824-837.

Choi, Y., H. Suh and J. Kim. 2001. Purification and properties of extracellular phytase from Bacillus sp. KHU-10. J. Protein Chem. 20: 287-292.

Elhadi, A. E., H. A. H. Osman, E. E. A. Ahmed, M. M. Ahmed, M. A. Omer and O. Simon. 2011. Screening and production of phytase from some bacterial genera. Int. J. Adv. Biol. Res. 1: 15-21.

Engelen, A. J., F. C. Van der Heeft, P. H. Randsdorp and E. L. Smit. 1994. Simple and rapid determination of phytase activity. J. AOAC Int. 77: 760-764.

Georgiev, D., M. Brazkova and S. Gargova. 2009. Comparative study of methods for increasing of cell wall permeability and disintegration of phytase producing yeast cells. Food Sci. Eng. Technol: 293-298.

Georgiev, D., V. Gotcheva, A. Angelov, A. Slavchev and S. Gargova. 2013. Phytase production by Candida melibiosica 2491 alkalophylic strain, Emir. J. Food Agric. 25: 342-348.

Georgiev, D., V. Gotcheva, A. Angelov, A. Slavchev and S. Gargova. 2013. Phytase production by Candida melibiosica 2491 alkalophylic strain, Emir. J. Food Agric. 25: 342-348.

Greiner, R., U. Konietzny and K. D. Jany. 1993. Purification and characterization of two phytases from Escherichia coli. Arch. Biochem. Biophys. 303: 107-113.

Guo, M. J., Y. P. Zhuang, J. Chu, S. L. Zhang, A. S. Xiong, R. H. Peng and Q. H. Yao. 2007. Production and purification of a novel thermostable phytase by Pichia pastoris FPHY 34 . Process Biochem. 42: 1660-1665.

Hartree, E. F. 1972. Determination of protein; A modification of the lowry method that gives a linear photometric response. Anal. Biochem. 48: 422-427.

Hubenova, Y., D. Georgiev and M. Mitov. 2014. Stable current outputs and phytate degradation by yeast-based biofuel cell. Yeast. 31: 343-348.

Hubenova, Y., E. Hubenova, E. Slavcheva and M. Mitov. 2017. The glyoxylate pathway contributes to enhanced extracellular electron transfer in yeast-based biofuel cell. Bioelectrochemistry. 116: 10-16.

Hubenova, Y. and M. Mitov. 2015a. Extracellular electron transfer in yeast-based biofuel cells: A review. Bioelectrochemistry. 106: 177-185.

Hubenova, Y. and M. Mitov. 2015b. Mitochondrial origin of extracelullar transferred electrons in yeast-based biofuel cells. Bioelectrochemistry. 106: 232-239.

In, M. J., S. W. Seo, D. C. Kim and N. S. Oh. 2009. Purification and biochemical properties of an extracellular acid phytase produced by the Saccharomyces cerevisiae CY strain. Process Biochem. 44: 122-126.

Laemmli, U. K. 1970. Cleavage of structural proteins during the assembli of the head of bacteriophage T4. Nature. 227: 680-685.

Lambrechts, C., H. Boze, G. Molin and P. Galzy. 1992. Utilization of phytate by some yeasts. Biotech. Letters. 14: 61-66.

Nayini, N. R. and P. Markakis. 1984. The phytase of yeast. Food Sci. Technol. 17: 126-132. 
Nuobariene, L., A. S. Hansen, L. Jespersen and N. Arneborg. 2011. Phytase-active yeasts from grain-based food and beer. J. Appl. Microbiol. 100: 1370-1380.

Quan, C., L. Zhang, Y. Wang and Y. Ohta. 2001. Production of phytase in a low phosphate medium by a novel yeast Candia krusei. J. Biosci. Bioeng. 92: 154-160.

Quan, C. 2002. Purification and properties of a phytase from Candida krusei WZ-001. J. Biosci. Bioeng. 94: 419-425.

Qvirist, L., E. Vorontsov, V. J. Vilg and T. Andlid. 2017. Strain improvement of Pichia kudriavzevii TY13 for raised phytase production and reduced phosphate repression. Microb. Biotechnol. 10: 341-353. doi:10.1111/1751-7915.12427.

Sano, K., H. Fukuhara and J. J. Nakamura. 1999. Phytase of the yeast Arxula adeninivorans. Biotech. Lett. 21: 33-38.

Segueilha, L., G. Moulin and P. Galzy. 1993. Reduction of phytate content in wheat bran and grandless cotton flour by Schwaniomyces castellii. J. Agric. Food Chem. 41. DOI: $10.1021 / \mathrm{jf00036a046.}$

Segueilha, L., C. Lambrechts, H. Boze, G. Moulin and P. Galzy. 1992. Purification and properties of the phytase from Schwaniomyces castellii. J. Ferment. Bioeng. 74: 7-11.

Spier, M. R., R. C. Fendrich, P. C. Almeida, M. Noseda, R. Greiner,
U. Konietzny, A. L. Woiciechowski, V. T. Soccol and C. R. Soccol. 2011. Phytase produced on citric byproducts: Purification and characterization. World J. Microbiol. Biotechnol. 27: 267-274.

Stanchev, V., D. Georgiev and S. Gargova. 2010. Mathematical modeling of the nutrient medium composition for the production of yeast phytase. Bulg. J. Agric. Sci. 16: 628-634.

Tseng, Y., S. Fang and S. Tseng. 2000. Isolation and haracterization of a novel phytase from Penicillium simplicissimum. Folia Microbiol. 45: 121-127.

Vochra, A., P. Kaur and T. Satyanarayana. 2011. Production, characteristics and application of the cell-bound phytase of Pichia anomala. Antonie van Leeuwenhoek. 99: 51-55. DOI: 10.1007/s10482-010-9498-1.

Yao, M. Z., Y. H. Zhang, W. L. Lu, M. Q. Hu, W. Wang and A. H. Liang. 2012. Phytases: Crystal structures, protein engineering and potential biotechnological applications. J. Appl. Microbiol. 112: 1-14.

Zhang, G., F. Dong, H. Wang, Q. Zhang and M. Tong. 2010. Purification, characterization, and cloning of a novel phytase with low $\mathrm{pH}$ optimum and strong proteolysis resistance from Aspergillus ficuum NTG-23. Bioresour. Technol. 101: 4125-4131. 